\title{
Life history and ontogenetic vertical migration of Neocalanus gracilis in the western North Pacific Ocean
}

\author{
Shinji Shimode ${ }^{1, *}$, Yutaka Hiroe ${ }^{2}$, Kiyotaka Hidaka ${ }^{2}$, Kazutaka Takahashi $^{3}$, \\ Atsushi Tsuda ${ }^{1}$ \\ ${ }^{1}$ Ocean Research Institute, University of Tokyo, 1-15-1 Minamidai, Nakano, Tokyo 164-8639, Japan \\ ${ }^{2}$ National Research Institute of Fisheries Science, Fisheries Research Agency, 2-12-4 Fukuura, Kanazawa, Yokohama, \\ Kanagawa 236-8648, Japan \\ ${ }^{3}$ Tohoku National Fisheries Research Institute, Fisheries Research Agency, 3-27-5, Shinhama-cho, Shiogama, \\ Miyagi 985-0001, Japan
}

\begin{abstract}
To better understand the life history and ontogenetic vertical migration of Neocalanus gracilis (Dana), geographical and seasonal change in the copepodid population structure was investigated in the western North Pacific. Multi-layered zooplankton samples were collected from $1000 \mathrm{~m}$ depth to the surface at 21 stations (ca. 15 to $48^{\circ} \mathrm{N}, 127^{\circ} \mathrm{E}$ to $159^{\circ} \mathrm{W}$ ) from September 2001 to June 2006 and from $200 \mathrm{~m}$ depth to the surface at a fixed station $\left(30^{\circ} \mathrm{N}, 138^{\circ} \mathrm{E}\right)$ from January 2003 to January 2004. N. gracilis was distributed in the southern part of the sampling area $<36^{\circ} \mathrm{N}$. Early copepodid stages ( $\mathrm{C} 1$ or $\mathrm{C} 2$ ) were always collected regardless of season, suggesting no seasonality in reproduction. In water columns of from 0 to $1000 \mathrm{~m}$ depth, $93 \%$ of the total copepodids occurred between the surface and $200 \mathrm{~m}$, and diel vertical migration (DVM) was not clearly observed, except for nonfeeding C6 males. Males were mainly distributed in deep layers $(<300 \mathrm{~m}$ depth) during the daytime, whereas they migrated to shallower layers during night, where the females were present. Our results suggest that a key factor controlling male DVM is a trade-off between mating with females and predation risk in the upper layer. The species also showed small-scale ontogenetic vertical migrations (OVM) of both developmental ascent ( $\mathrm{C} 1$ to $\mathrm{C} 3$ ) and descent ( $\mathrm{C} 5$ to $\mathrm{C} 6$ ). The relatively deeper distribution of Stage C1 individuals exhibiting oil droplets in their bodies implies non-feeding early developmental stages, which is beneficial in avoiding predatory risk and surviving in oligotrophic tropical waters. On an evolutionary time scale, these adaptive traits to oligotrophic environments may have allowed the genus to extend into the subarctic Pacific, which is characterized as a 'high nutrient, low chlorophyll' area, and the OVM pattern might be modified to synchronize the life history to the seasonality of local production.
\end{abstract}

KEY WORDS: Neocalanus gracilis $\cdot$ Ontogenetic vertical migration $\cdot$ Life history $\cdot$ Diel vertical migration

Resale or republication not permitted without written consent of the publisher

\section{INTRODUCTION}

The genus Neocalanus currently consists of 6 species, i.e. $N$. flemingeri, $N$. plumchrus, $N$. cristatus, $N$. tonsus, $N$. gracilis and $N$. robustior. The first 4 species are dominant, large, grazing copepods in subpolar regions. $N$. flemingeri, $N$. plumchrus and N. cristatus inhabit only the subarctic Pacific, whereas $N$. tonsus is distributed circumglobally in the subantarctic waters. These subpolar Neocalanus species are known to perform seasonal ontogenetic vertical migration (OVM) between the surface and deep layers (e.g. Mackas \& Tsuda 1999, Bradford-Grieve et al. 2001). They graze in the surface layers during the spring to early summer seasons to store lipid in their bodies (e.g. Ohman 1987, Conover 1988, Tsuda et al. 2001). In the summer season, late copepodids migrate into deep water as overwintering dormant stages, and, before spring, they de- 
velop into adults that reproduce in the deep layers. Through ontogenetic migration, they are considered to play an important role in carbon flux in the pelagic ecosystem, estimated at $1000 \mathrm{~m}$ depth to be $5.0 \mathrm{~g} \mathrm{C} \mathrm{m}^{-2} \mathrm{yr}^{-1}$ by 3 Neocalanus species in the western subarctic $\mathrm{Pa}$ cific (Kobari et al. 2003) and from 1.7 to $3.4 \mathrm{~g} \mathrm{C} \mathrm{m}^{-2} \mathrm{yr}^{-1}$ by $N$. tonsus in the Southern Ocean (Bradford-Grieve et al. 2001). These OVM patterns of Neocalanus species are considered to be adaptations to high seasonal variations in environmental conditions and generally low phytoplankton production in the subarctic Pacific and the Southern Ocean, which are known as 'high nutrient, low chlorophyll (HNLC)' regions (e.g. Martin \& Fitzwater 1988, Boyd et al. 2000, Tsuda et al. 2003).

In contrast to the high latitude species, there have been a few studies on the ecology of Neocalanus gracilis and $N$. robustior, which are distributed in subtropical and tropical oceans. Mullin \& Evans (1976) have described the horizontal and vertical distribution of the 2 warm-water species in the Pacific Ocean. According to their results, the 2 Neocalanus species were most abundant in the eastern Central North Pacific and mainly distributed in the surface layer $(<200 \mathrm{~m}$ depth). They also reported no seasonal changes in abundances of late copepodid populations (Stages C4 to C6) of the 2 species. Although the vertical distribution of the 2 species has been described (e.g. Roe 1972, Hays et al. 1997, Andersen et al. 2001), patterns in diel vertical migration (DVM) have differed among the cited studies.

In a recent article by Machida et al. (2006), the phylogenic evolution of the genus Neocalanus was proposed following molecular analysis. Their results indicated that $N$. gracilis and $N$. robustior occupied the most basal phylogenetic position and that the subpolar species have diverged subsequently. Therefore, investigation of the ecology of the tropical and subtropical Neocalanus species may provide a key to understanding how subpolar species of the genus have adapted to the HNLC regions. In the present study, to clarify the life history of the tropical and subtropical Neocalanus spp., geographical distribution, DVM, OVM and seasonal change in the copepodid populations were investigated in the western North Pacific Ocean. The aim of the present study was to determine whether these low-latitude Neocalanus species have ecological characteristics in common with the high-latitude species and to discuss a possible hypothesis for adaptive radiation of Neocalanus species into the HNLC regions.

\section{MATERIALS AND METHODS}

To investigate the geographical distribution of Neocalanus gracilis and $N$. robustior in the western North Pacific Ocean, zooplankton sampling was carried out during research cruises KH-03-02, KH-06-01 and KH06-02, of the RV 'Hakuho-Maru', Ocean Research Institute, University of Tokyo, and C-01 of the RV 'Hakurei-Maru No. 2', Japan Oil, Gas and Metals National Corporation. Details for each cruise and sampling station are shown in Table 1 and Fig. 1. Zooplankton samples were collected by vertical tows using a vertical multiple plankton sampler (VMPS; Terazaki \& Tomatsu 1997). Mouth opening areas and mesh sizes of VMPSs were $0.25 \mathrm{~m}^{2}$ and $330 \mu \mathrm{m}$ during Cruises $\mathrm{KH}-03-02$ and KH-06-02, $0.25 \mathrm{~m}^{2}$ and $100 \mu \mathrm{m}$ during $\mathrm{KH}-06-01$, and $1 \mathrm{~m}^{2}$ and $100 \mu \mathrm{m}$ during C-01, respectively. Sampling layers were also different at each station (see Table 1), and samples collected from below $1000 \mathrm{~m}$ layers were not used for the present study. At St. 15 (KH-06-02), because of trouble with the VMPS, only 1 sample was collected from $600 \mathrm{~m}$ to the surface. Thus, the sample was used only for the horizontal distribution analysis.

To analyze seasonal changes in population structures and day/night vertical distribution of Neocalanus species, zooplankton samples were also collected at a fixed station (St. $\mathrm{B} 01 ; 30^{\circ} 00^{\prime} \mathrm{N}, 138^{\circ} 00^{\prime} \mathrm{E}$; Fig. 1) located in the western part of the North Pacific Ocean, during the research cruises of the RV 'Soyo-Maru', conducted as part of the O-line monitoring program by the Fisheries Research Agency, Japan. Day/night zooplankton sampling was carried out using a multiple opening and closing net with an environmental sensing system (MOCNESS, $0.25 \mathrm{~m}^{2}$ net mouth opening,

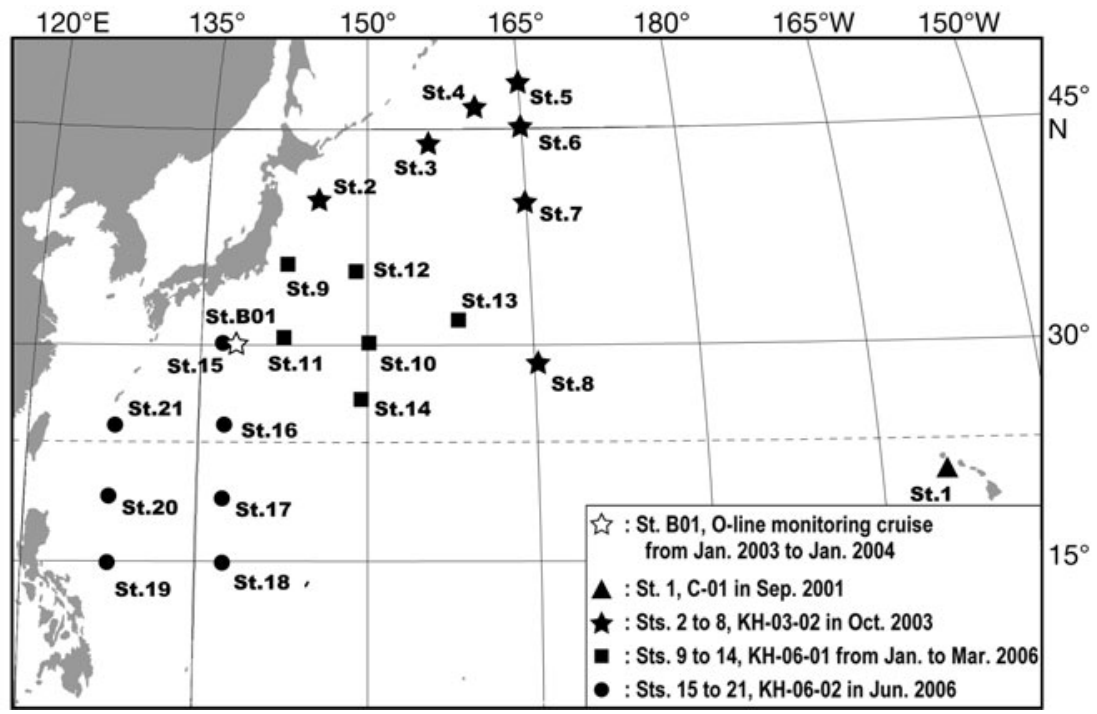

Fig. 1. Sampling stations in the present study 
Table 1. Details of the sampling cruises and stations in the present study. Station names in parentheses indicate original names used in the cruise reports. Sampling layers-a: 0-50, 50-100, 100-200, 200-300, 300-400, 400-600 and 600-800 m; b: 0-200, 200-500, 500-1000 and 1000-2000 m; c: 0-50, 50-100, 100-200, 200-500, 500-1000 and 1000-2000 m; d: 0-50, 50-100, $100-200,200-350,350-500$ and $500-1000 \mathrm{~m}$; e: $0-100,100-200,200-500$ and $500-1000 \mathrm{~m}$

\begin{tabular}{|c|c|c|c|c|c|c|}
\hline Cruise No. & $\begin{array}{l}\text { Station } \\
\text { name }\end{array}$ & Position & Date & Local time & $\begin{array}{l}\text { Sampling } \\
\text { layers }\end{array}$ & Day/Night \\
\hline C-01 & $\begin{array}{l}1(\mathrm{H} 2) \\
1(\mathrm{H} 2)\end{array}$ & $\begin{array}{l}21^{\circ} 57^{\prime} \mathrm{N}, 159^{\circ} 17^{\prime} \mathrm{W} \\
21^{\circ} 57^{\prime} \mathrm{N}, 159^{\circ} 17^{\prime} \mathrm{W}\end{array}$ & $\begin{array}{l}18 \text { Sep } 2001 \\
18 \text { Sep } 2001\end{array}$ & $\begin{array}{l}15: 08-16: 10 \\
20: 05-21: 09\end{array}$ & $\begin{array}{l}\mathrm{a} \\
\mathrm{a}\end{array}$ & $\begin{array}{l}\text { Day } \\
\text { Night }\end{array}$ \\
\hline KH-03-02 & $\begin{array}{l}2(1) \\
3(4) \\
4(5) \\
5(6) \\
6(7) \\
7(8) \\
8(10)\end{array}$ & $\begin{array}{l}40^{\circ} 30^{\prime} \mathrm{N}, 146^{\circ} 00^{\prime} \mathrm{E} \\
44^{\circ} 00^{\prime} \mathrm{N}, 155^{\circ} 00^{\prime} \mathrm{E} \\
47^{\circ} 00^{\prime} \mathrm{N}, 160^{\circ} 00^{\prime} \mathrm{E} \\
48^{\circ} 30^{\prime} \mathrm{N}, 165^{\circ} 00^{\prime} \mathrm{E} \\
45^{\circ} 00^{\prime} \mathrm{N}, 165^{\circ} 00^{\prime} \mathrm{E} \\
40^{\circ} 00^{\prime} \mathrm{N}, 165^{\circ} 00^{\prime} \mathrm{E} \\
28^{\circ} 00^{\prime} \mathrm{N}, 165^{\circ} 00^{\prime} \mathrm{E}\end{array}$ & $\begin{array}{r}2 \text { Oct } 2003 \\
5 \text { Oct } 2003 \\
6 \text { Oct } 2003 \\
7 \text { Oct } 2003 \\
8 \text { Oct } 2003 \\
9 \text { Oct } 2003 \\
12 \text { Oct } 2003\end{array}$ & $\begin{array}{l}11: 28-13: 02 \\
05: 59-07: 49 \\
14: 00-15: 31 \\
12: 41-14: 12 \\
12: 11-13: 43 \\
22: 02-23: 51 \\
13: 49-15: 25\end{array}$ & $\begin{array}{l}\mathrm{b} \\
\mathrm{b} \\
\mathrm{b} \\
\mathrm{b} \\
\mathrm{b} \\
\mathrm{b} \\
\mathrm{b}\end{array}$ & $\begin{array}{l}\text { Day } \\
\text { Day } \\
\text { Day } \\
\text { Day } \\
\text { Day } \\
\text { Night } \\
\text { Day }\end{array}$ \\
\hline KH-06-01 & $\begin{array}{l}9(105) \\
10(165) \\
11(181) \\
11(182) \\
11(184) \\
11(185) \\
12(281) \\
13(329) \\
14(372)\end{array}$ & $\begin{array}{l}36^{\circ} 31^{\prime} \mathrm{N}, 142^{\circ} 06^{\prime} \mathrm{E} \\
31^{\circ} 01^{\prime} \mathrm{N}, 150^{\circ} 59^{\prime} \mathrm{E} \\
32^{\circ} 30^{\prime} \mathrm{N}, 142^{\circ} 27^{\prime} \mathrm{E} \\
32^{\circ} 31^{\prime} \mathrm{N}, 142^{\circ} 23^{\prime} \mathrm{E} \\
32^{\circ} 30^{\prime} \mathrm{N}, 142^{\circ} 18^{\prime} \mathrm{E} \\
32^{\circ} 29^{\prime} \mathrm{N}, 142^{\circ} 15^{\prime} \mathrm{E} \\
35^{\circ} 13^{\prime} \mathrm{N}, 147^{\circ} 31^{\prime} \mathrm{E} \\
32^{\circ} 22^{\prime} \mathrm{N}, 158^{\circ} 49^{\prime} \mathrm{E} \\
25^{\circ} 45^{\prime} \mathrm{N}, 147^{\circ} 56^{\prime} \mathrm{E}\end{array}$ & $\begin{array}{r}31 \text { Jan } 2006 \\
7 \text { Feb } 2006 \\
10 \text { Feb } 2006 \\
10 \text { Feb } 2006 \\
10 \text { Feb } 2006 \\
11 \text { Feb } 2006 \\
4 \text { Mar } 2006 \\
\text { 8 Mar } 2006 \\
13 \text { Mar } 2006\end{array}$ & $\begin{array}{l}10: 20-12: 17 \\
07: 04-08: 54 \\
10: 30-11: 36 \\
16: 07-17: 19 \\
21: 55-23: 02 \\
04: 10-05: 23 \\
16: 51-18: 45 \\
07: 08-08: 24 \\
10: 48-12: 02\end{array}$ & $\begin{array}{l}\text { c } \\
\text { c } \\
d \\
d \\
d \\
d \\
\text { c } \\
d \\
d\end{array}$ & $\begin{array}{l}\text { Day } \\
\text { Day } \\
\text { Day } \\
\text { Day } \\
\text { Night } \\
\text { Night } \\
\text { Day } \\
\text { Day } \\
\text { Day }\end{array}$ \\
\hline KH-06-02 & $\begin{array}{l}15(1) \\
16(3) \\
17(5) \\
18(6) \\
19(7) \\
20(8) \\
21(9)\end{array}$ & $\begin{array}{l}30^{\circ} 00^{\prime} \mathrm{N}, 137^{\circ} 00^{\prime} \mathrm{E} \\
25^{\circ} 00^{\prime} \mathrm{N}, 137^{\circ} 00^{\prime} \mathrm{E} \\
20^{\circ} 00^{\prime} \mathrm{N}, 137^{\circ} 00^{\prime} \mathrm{E} \\
15^{\circ} 00^{\prime} \mathrm{N}, 137^{\circ} 00^{\prime} \mathrm{E} \\
15^{\circ} 00^{\prime} \mathrm{N}, 127^{\circ} 00^{\prime} \mathrm{E} \\
20^{\circ} 00^{\prime} \mathrm{N}, 127^{\circ} 00^{\prime} \mathrm{E} \\
25^{\circ} 00^{\prime} \mathrm{N}, 127^{\circ} 00^{\prime} \mathrm{E}\end{array}$ & $\begin{array}{r}3 \text { Jun } 2006 \\
6 \text { Jun } 2006 \\
8 \text { Jun } 2006 \\
9 \text { Jun } 2006 \\
\text { 18 Jun } 2006 \\
\text { 20 Jun } 2006 \\
\text { 21 Jun } 2006\end{array}$ & $\begin{array}{l}08: 55-09: 54 \\
00: 44-01: 43 \\
05: 18-06: 18 \\
16: 30-17: 25 \\
18: 50-19: 51 \\
01: 39-02: 36 \\
12: 47-13: 48\end{array}$ & $\begin{array}{l}\text { e } \\
\text { e } \\
\text { e } \\
\text { e } \\
\text { e } \\
\text { e } \\
\text { e }\end{array}$ & $\begin{array}{l}\text { Day } \\
\text { Night } \\
\text { Night } \\
\text { Day } \\
\text { Night } \\
\text { Night } \\
\text { Day }\end{array}$ \\
\hline
\end{tabular}

$64 \mu \mathrm{m}$ mesh size). Sampling layers were from the surface to $200 \mathrm{~m}$ in eight $25 \mathrm{~m}$ horizons. The samples collected on 13 January, 13 May, 6 July, 9 November 2003 and 18 January 2004 were analyzed for the present study. Surface temperature and salinity were recorded by a single CTD observation during each cruise.

The zooplankton samples were subsequently fixed and preserved in buffered $10 \%$ (5\% in the samples at St. B01) formalin seawater solutions. The individual developmental stages (C1 to C6) of Neocalanus gracilis and $N$. robustior were counted in $1 / 1,1 / 2$, or $1 / 4$ of each zooplankton sample. Adult stages (C6) were separated by gender. After enumerating individuals in the samples, the numbers of individuals per cubic meter were calculated from the volumes of water that passed through the nets and the frequency of the sample splits. However, the VMPS filtration efficiencies calculated using a flow meter were available only for Cruise C-01, and ranged from 90 to $99 \%$. Therefore, the efficiency for the other cruises was assumed to be $90 \%$, the average for these types of nets. To investigate the DVM and OVM of each stage of the species, the median depth, above and below which $50 \%$ of the individuals were collected $\left(D_{50 \%}\right.$; Pennak 1943), was calculated for each copepodid stage. The depths above which $10 \%\left(D_{10 \%}\right), 25 \%\left(D_{25 \%}\right), 75 \%\left(D_{75 \%}\right)$ and $90 \%$ $\left(\mathrm{D}_{90 \%}\right)$ of the individuals resided were also calculated. Samples were categorized as either daytime or nighttime, based on the local times of the sunrise and sunset. Variations in $\mathrm{D}_{50 \%}$ among day/night and among stages were examined with a 2-way analysis of variance (ANOVA) and a Tukey-Kramer test.

\section{RESULTS}

\section{Geographical distribution of Neocalanus gracilis and $N$. robustior in the western part of the North Pacific Ocean}

Abundances of Neocalanus gracilis were always higher than those of $N$. robustior (Table 2). In particular, young (C1 and C2) and adult (C6) stages of $N$. robustior were rarely collected from our sampling stations, while $N$. gracilis were sufficiently abundant to analyze distributional patterns and seasonal changes. For this reason, analysis was only carried out for $N$. gracilis in the present study. 
Table 2. Neocalanus gracilis and Neocalanus robustior. Copepodid abundances by developmental stage at stations in the western North Pacific Ocean. -: no samples found

\begin{tabular}{|c|c|c|c|c|c|c|c|c|c|c|c|c|c|c|c|c|}
\hline \multirow[t]{2}{*}{ Stations } & \multicolumn{8}{|c|}{$-N$. gracilis (ind. $\mathrm{m}^{-2}$ ) } & \multicolumn{8}{|c|}{$-N$. robustior (ind. $\mathrm{m}^{-2}$ ) } \\
\hline & $\mathrm{C} 1$ & $\mathrm{C} 2$ & $\mathrm{C} 3$ & $\mathrm{C} 4$ & C5 & $\mathrm{C} 6 \mathrm{~F}$ & C6M & Total & $\mathrm{C} 1$ & $\mathrm{C} 2$ & C3 & $\mathrm{C} 4$ & $\mathrm{C} 5$ & $\mathrm{C} 6 \mathrm{~F}$ & $\mathrm{C} 6 \mathrm{M}$ & Total \\
\hline St. $1^{\mathrm{a}}$ & 0.5 & 8.0 & 8.0 & 12.8 & 5.9 & 3.2 & 4.7 & 43.2 & - & 11.3 & 11.8 & 8.0 & 1.7 & - & - & 32.8 \\
\hline St. 8 & 8.9 & 48.9 & 40.0 & 75.6 & 111.1 & 71.1 & 17.8 & 373.3 & - & - & - & - & - & - & - & - \\
\hline St. 9 & 8.9 & 8.9 & - & - & - & - & - & 17.8 & - & - & - & - & - & - & - & - \\
\hline St. 10 & 8.9 & 26.7 & 71.1 & 71.1 & 35.6 & 8.9 & - & 222.2 & - & - & - & - & - & - & - & - \\
\hline St. $11^{a}$ & 6.7 & 37.8 & 75.6 & 91.1 & 40.0 & 16.7 & 3.3 & 271.1 & 2.2 & 4.4 & 1.1 & 2.2 & 4.4 & 2.2 & - & 16.7 \\
\hline St. 12 & 4.4 & 8.9 & 40.0 & 26.7 & 8.9 & 4.4 & 13.3 & 106.7 & - & 4.4 & - & - & - & 4.4 & 4.4 & 13.3 \\
\hline St. 13 & - & 13.3 & 4.4 & 13.3 & 53.3 & 26.7 & 8.9 & 120.0 & - & - & - & - & - & - & - & - \\
\hline St. 14 & - & 26.7 & 17.8 & 8.9 & 13.3 & 22.2 & - & 88.9 & - & - & - & 8.9 & - & - & - & 8.9 \\
\hline St. 15 & 4.4 & 53.3 & 62.2 & 35.6 & 53.3 & 13.3 & 13.3 & 235.6 & - & - & - & - & - & - & - & - \\
\hline St. 16 & 4.4 & 22.2 & 48.9 & 40.0 & 48.9 & 8.9 & - & 173.3 & - & - & - & - & - & - & - & - \\
\hline St. 17 & - & 22.2 & 26.7 & 22.2 & 17.8 & 13.3 & 26.7 & 128.9 & - & - & - & - & - & 4.4 & - & 4.4 \\
\hline St. 18 & 44.4 & 48.9 & 4.4 & 13.3 & 44.4 & 26.7 & 22.2 & 204.4 & - & - & 4.4 & 4.4 & - & - & - & 8.9 \\
\hline St. 19 & 8.9 & - & 17.8 & 4.4 & 13.3 & 4.4 & 4.4 & 53.3 & - & - & - & - & - & - & - & - \\
\hline St. 20 & 17.8 & 26.7 & 8.9 & 35.6 & 62.2 & 44.4 & 26.7 & 222.2 & - & - & - & - & 4.4 & - & - & 4.4 \\
\hline St. 21 & 4.4 & 4.4 & 8.9 & - & 35.6 & 8.9 & 8.9 & 71.1 & - & - & - & - & - & - & - & - \\
\hline \multicolumn{17}{|l|}{ St. B01 } \\
\hline Jan $2003^{a}$ & 44.1 & 172.5 & 292.9 & 413.2 & 398.5 & 315.8 & 18.1 & 1655.1 & - & - & 8.2 & - & 4.0 & - & - & 12.1 \\
\hline May $2003^{a}$ & - & 87.1 & 83.3 & 132.3 & 66.7 & 72.7 & - & 442.1 & - & - & - & - & 2.2 & - & - & 2.2 \\
\hline Jul $2003^{a}$ & 2.4 & 83.4 & 477.9 & 547.1 & 253.6 & 78.7 & 6.0 & 1449.2 & - & - & - & 1.3 & 0.8 & - & - & 2.1 \\
\hline Nov $2003^{a}$ & 14.3 & 54.3 & 171.6 & 411.6 & 486.1 & 138.0 & 4.5 & 1280.4 & - & - & - & - & 4.6 & - & - & 4.6 \\
\hline $\operatorname{Jan} 2003^{\mathrm{a}}$ & 12.8 & 82.8 & 133.9 & 122.1 & 197.2 & 266.8 & 1.2 & 816.7 & 2.0 & - & 6.0 & - & 2.2 & - & - & 10.2 \\
\hline
\end{tabular}

Neocalanus gracilis were collected during all research cruises (Fig. 2), although each cruise was conducted in a different season (Table 1). The species was collected only from the southern part of the study area (latitudes south of ca. $35^{\circ} \mathrm{N}$ ) in the western North Pacific Ocean. The maximum abundance of the species was recorded at St. 8 (373.3 ind. $\mathrm{m}^{-2}$ ), and high abundances (>200 ind. $\mathrm{m}^{-2}$ ) were observed at Sts. 10 (222.2 ind. $\mathrm{m}^{-2}$ ), 11 (271.1 ind. $\mathrm{m}^{-2}$ ), 15 (235.6 ind. $\mathrm{m}^{-2}$ ), 18 (204.4 ind. $\mathrm{m}^{-2}$ ) and 20 (222.2 inds. $\mathrm{m}^{-2}$ ). The minimum was 17.8 ind. $\mathrm{m}^{-2}$ at St. 9. The percentage frequency of each copepodid stage of $N$. gracilis varied among the stations, and those of C1 and C6M (4.5 and $5.2 \%$ in average abundances, respectively) were relatively lower than the other stages. The younger stages (C1, C2, or C3) were always collected regardless of the differences in the seasons of each cruise.

The vertical distribution of Neocalanus gracilis was similar among stations (Figs. $3 \& 4$ ). Although the total abundance at each station varied, $N$. gracilis was mainly distributed within the upper $200 \mathrm{~m}$ at all stations; in this depth layer $91.4 \%$ of the total individuals was collected. However, most $(83.5 \%)$ of C6 males were distributed below $200 \mathrm{~m}$ and some C6 males were collected between 500 and $1000 \mathrm{~m}$ at Sts. 1, 8, 17, 18, 19,20 and 21.

\section{Seasonal changes of Neocalanus gracilis population at St. B01}

Seasonal changes in the daytime surface temperature and salinity at St. B01 are shown in Fig. 5a. Lower temperatures $\left(<22^{\circ} \mathrm{C}\right)$ were recorded in January, May 2003 and January 2004, while higher values $\left(>25^{\circ} \mathrm{C}\right)$ were recorded from July to November 2003. Seasonal change in the surface salinity was inversely related to temperature. The salinity was higher (>34.8) in January, May 2003 and January 2004; the lowest value (34.6) was recorded in November 2003.

The highest total abundance of Neocalanus gracilis collected from $200 \mathrm{~m}$ depth to the surface was 938.5 ind. $\mathrm{m}^{-2}$ during the night in January 2003, and the lowest was 112.0 ind. $\mathrm{m}^{-2}$ during the night in May 2003 (Fig. 5b). Seasonal changes in abundance were not apparent, although abundance in May 2003 was low $\left(\right.$ day $=330.1$ ind $\mathrm{m}^{-2}$, night $=112.0$ ind. $\mathrm{m}^{-2}$ ). Abundances were not significantly different (paired t-test, $\mathrm{p}>0.05$ ) between day and night. Furthermore, all copepodid stages of the species were collected throughout the sampling period, except in May 2003 (Fig. 5c). During the sampling period, the proportions of Stages C1 and C2 in the population were relatively small (1.2 and 9.7\%, respectively), while more than 


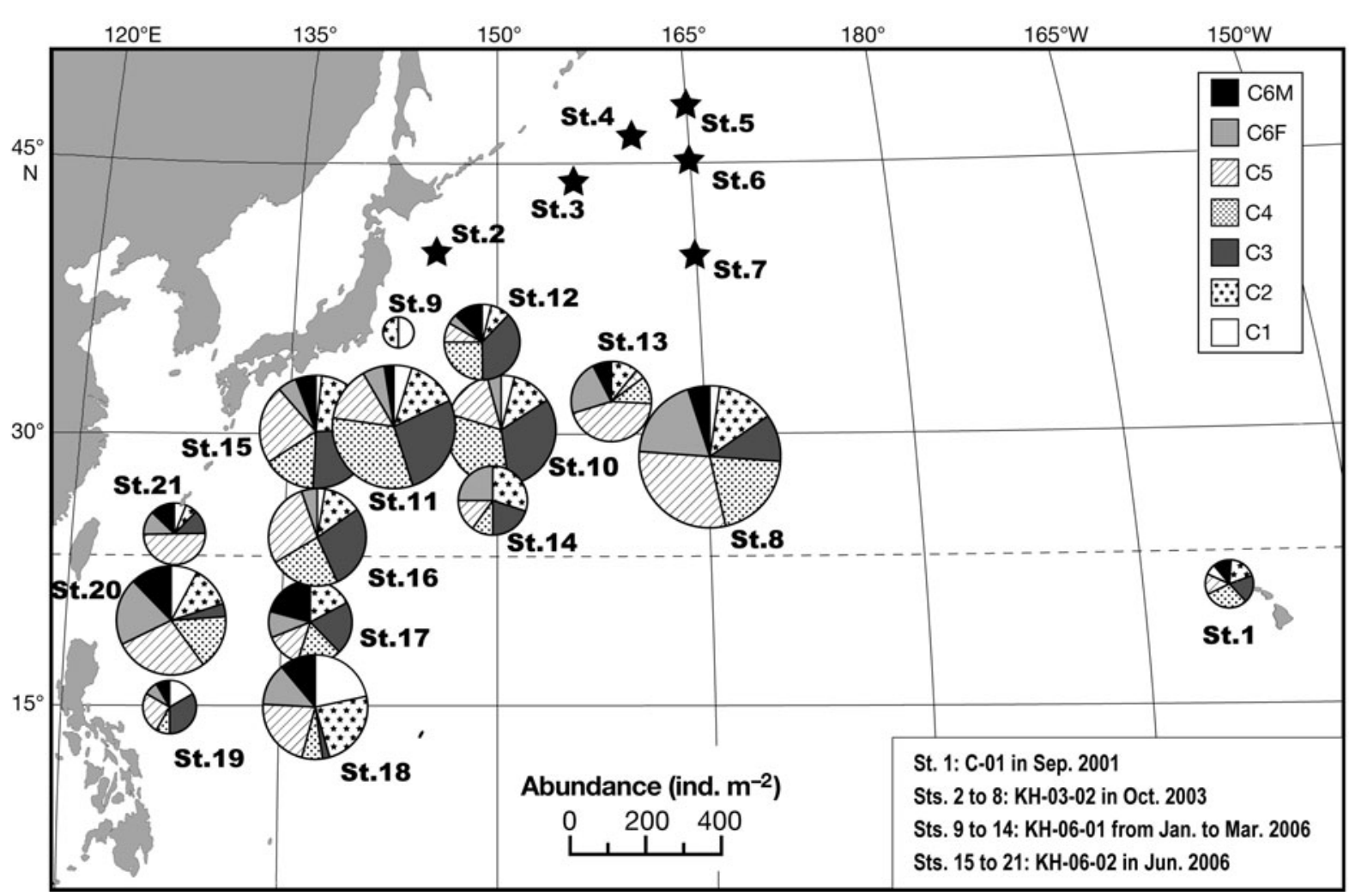

Fig. 2. Neocalanus gracilis. Geographical distribution of copepodid (C1 to C5) and adult (C6M and C6F) stages at 21 stations in the western North Pacific. N. gracilis was only collected at 15 stations. At the rest of the stations ( $\star$ ), the species was not found. Scale bar refers to diameter of pie chart

half (ca. $70 \%$ ) of the abundance was comprised of older stages (C4 to C6), except for adult males (C6M). C6 males had the lowest frequency $(0.4 \%)$, and they were collected only at night, except for the day samples in July 2003 (0.1 ind. $\mathrm{m}^{-2}, 0.2 \%$ during the day).

Seasonal change in the vertical distribution of Neocalanus gracilis was not apparent either (Fig. 6). Night distributions of total copepodid abundances seemed to be shallower than those during daytime in each month. However, average values $( \pm \mathrm{SD})$ of day/night $\mathrm{D}_{50 \%}$ calculated for the total copepodid populations were $66.0 \pm$ 15.7 and $62.3 \pm 6.3 \mathrm{~m}$, respectively, and the difference was not significant (paired $t$-test, $\mathrm{p}>0.05$ ).

\section{Ontogenetic and day/night vertical migrations of Neocalanus gracilis}

To analyze vertical migration patterns of Neocalanus gracilis, $\mathrm{D}_{10 \%}$ to $\mathrm{D}_{90 \%}$ values were calculated for each developmental stage collected from the surface to $1000 \mathrm{~m}$ during the 4 cruises KH-03-02, KH-0601, KH-06-02 and C-01 (from the surface to $800 \mathrm{~m}$ during C-01; Fig. 7a) and from the surface to $200 \mathrm{~m}$ depth at St. B01 (Fig. 7b). Two-way ANOVA showed no significant difference in $\mathrm{D}_{50 \%}$ between day and night, whereas $\mathrm{D}_{50 \%}$ values among copepodid stages were significantly different (Table 3). At St. B01, $\mathrm{D}_{50 \%}$ of $\mathrm{C} 1$ (day/night average $\pm \mathrm{SD}=137 \pm 36 \mathrm{~m}$ ) was significantly deeper (Tukey-Kramer test, p < 0.05) than $\mathrm{D}_{50 \%}$ values of the other stages, except for C6M. In the sampling from $1000 \mathrm{~m}$ depth at the other stations, $\mathrm{D}_{50 \%}$ of Stage C6M (day/night average $\pm \mathrm{SD}=393 \pm$ $128 \mathrm{~m}$ ) was significantly deeper (Tukey-Kramer test, $\mathrm{p}<0.05)$ than $\mathrm{D}_{50 \%}$ values of the other stages. The results of the vertical distributions from the 2 different sampling depths were almost identical, except for C6F and C6M. For Stages C1 to C5, $\mathrm{D}_{50 \%}$ values were restricted to the upper $200 \mathrm{~m}$ layer, during both day and night, and tended to become shallower with development. At St. B01 (Fig. 7b), $\mathrm{D}_{50 \%}$ of C6M were in a narrow and shallow range $(<125 \mathrm{~m}$ depth in both day and night), and the $\mathrm{D}_{50 \%}$ values of C6F were similar to those of $\mathrm{C} 5$ ( $<60 \mathrm{~m}$ in both day and night). In contrast, $\mathrm{D}_{50 \%}$ of the adults, particularly C6M, were deeper than the $\mathrm{D}_{50 \%}$ values of the other stages at the other stations (Fig. 7a). In addition, depth ranges between $\mathrm{D}_{25 \%}$ and $\mathrm{D}_{75} \%$ of $\mathrm{C} 6 \mathrm{~F}$ and $\mathrm{C} 6 \mathrm{M}$, in which $50 \%$ of the population was collected, were relatively wide compared to the ranges of other stages. The depth range of C6F extended both upward and down- 


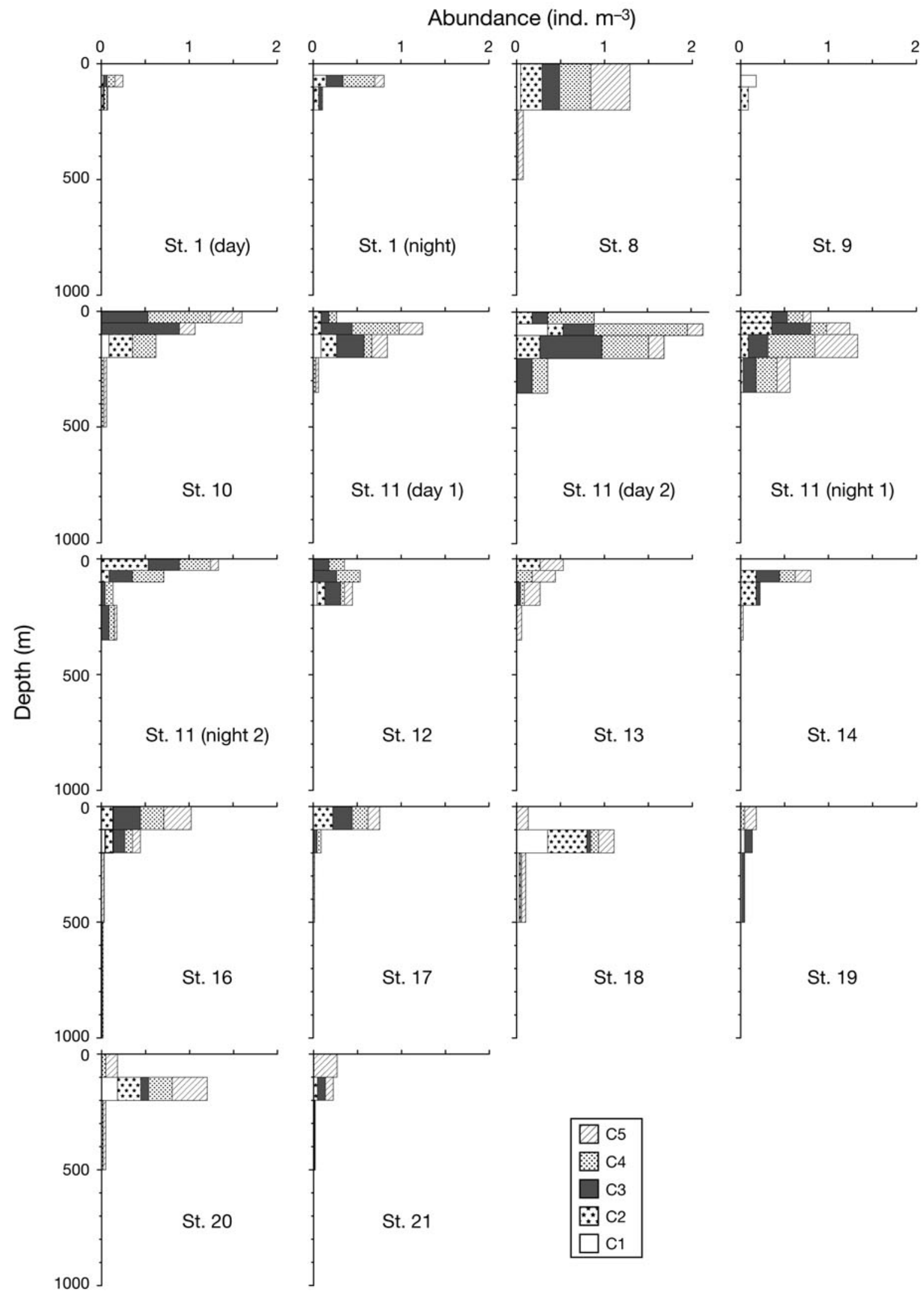

Fig. 3. Neocalanus gracilis. Vertical distribution of copepodid stages (C1 to C5) at 14 stations in the western North Pacific 


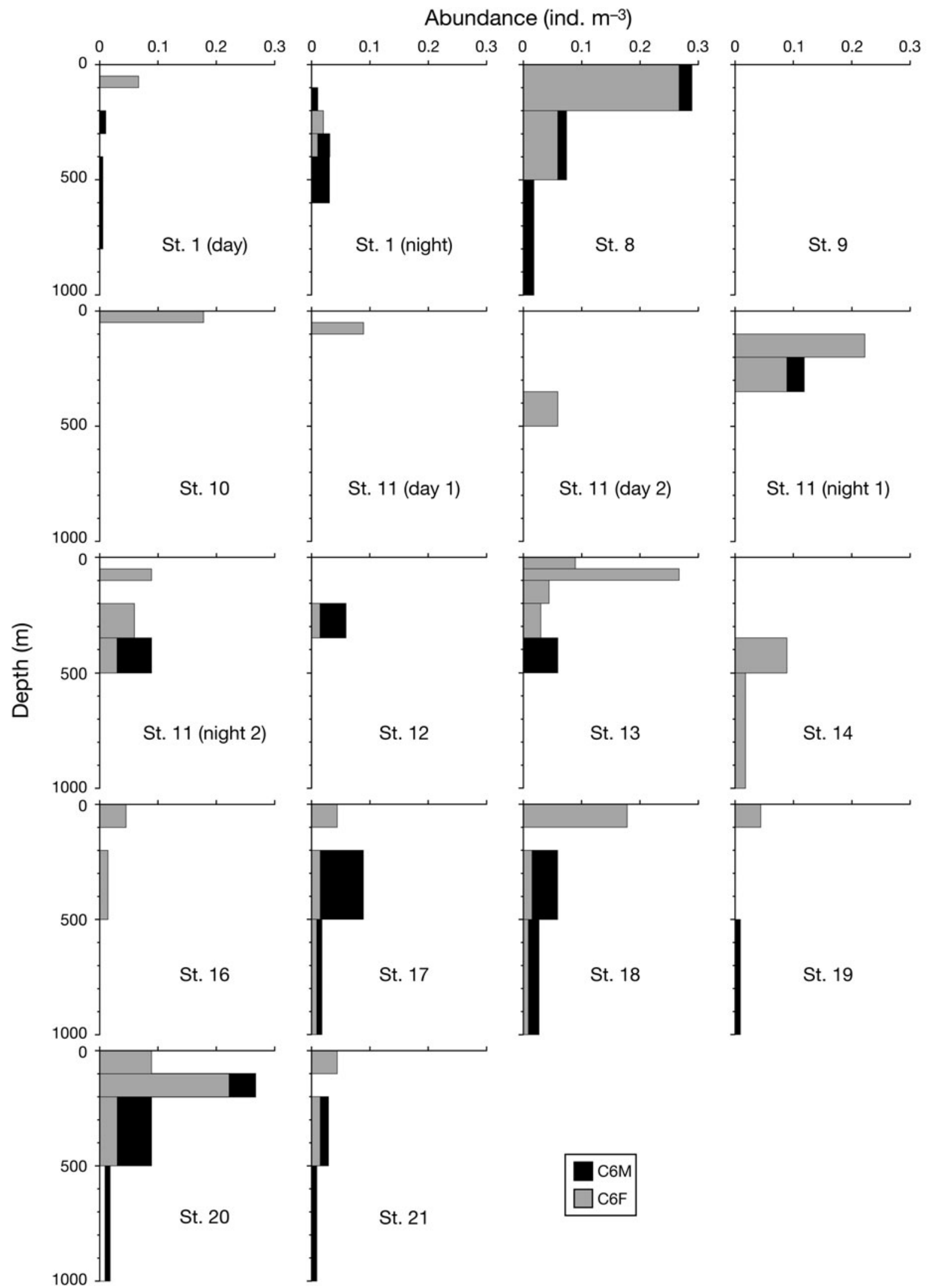

Fig. 4. Neocalanus gracilis. Vertical distribution of adults (C6F and C6M) at 14 stations in the western North Pacific 

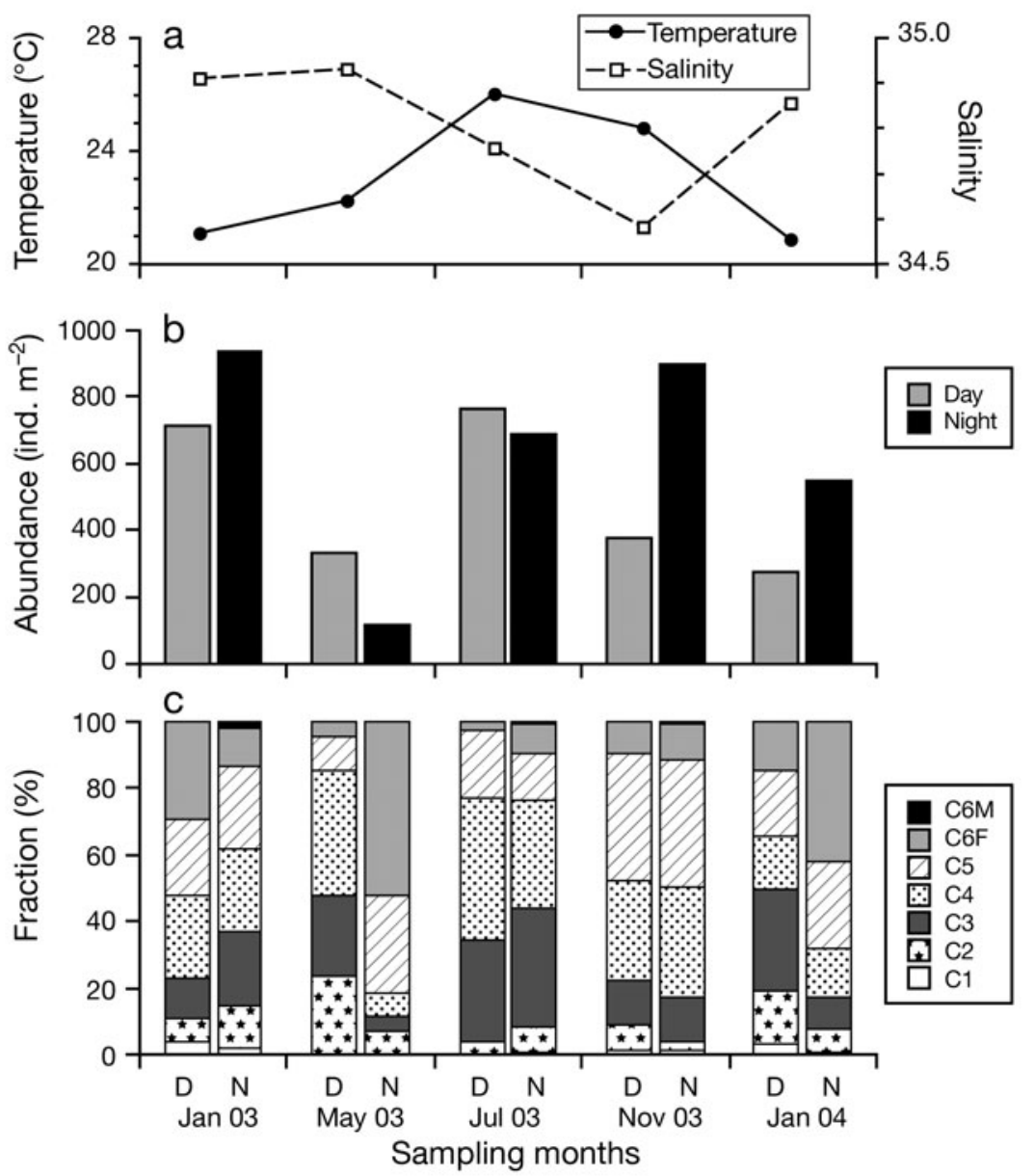

Fig. 5. Neocalanus gracilis, St. B01. Seasonal changes in (a) temperature and salinity (b) total copepodid abundances, and (c) developmental stage compositions

Table 3. Neocalanus gracilis. Summary of the 2-way ANOVAs performed on $\mathrm{D}_{50 \%}$ values of $N$. gracilis collected from 2 different sampling depths (0 to 1000 and 0 to $100 \mathrm{~m}$ ). DN: day or night samplings; S: copepodid stages

\begin{tabular}{|llcrrrc|}
\hline Sampling depth & Effect & df & \multicolumn{1}{c}{ SS } & MS & $F$ & p \\
\hline 0-1000 m & DN & 1 & 16886.15 & 16886.15 & 2.72 & 0.102 \\
& S & 6 & 873862.38 & 145643.73 & 23.46 & $<0.0001$ \\
& DN $\times$ S & 6 & 15166.63 & 2527.77 & 0.41 & 0.873 \\
& Residual & 94 & 583604.53 & 6208.56 & & \\
$0-100 \mathrm{~m}$ & DN & 1 & 819.05 & 819.05 & 1.07 & 0.306 \\
& S & 6 & 40008.33 & 6668.06 & 8.72 & $<0.0001$ \\
& DN $\times$ S & 6 & 4137.31 & 689.55 & 0.90 & 0.501 \\
& Residual & 48 & 36698.80 & 764.56 & & \\
\hline
\end{tabular}

ward in night collections $\left(\mathrm{D}_{25 \%}=103 \mathrm{~m}, \mathrm{D}_{75 \%}=243 \mathrm{~m}\right)$, whereas the range of $\mathrm{C} 6 \mathrm{M}$ shifted only upward and became narrower $\left(D_{25 \%}=276 \mathrm{~m}, \mathrm{D}_{75 \%}=426 \mathrm{~m}\right)$ than that during daytime $\left(\mathrm{D}_{25 \%}=327 \mathrm{~m}, \mathrm{D}_{75 \%}=573 \mathrm{~m}\right)$.

\section{DISCUSSION}

Continuous breeding is a common trait among copepod species inhabiting tropical waters (Webber \& Roff 1995, Hopcroft \& Roff 1998). Mullin \& Evans (1976) reported no seasonality in abundances of Neocalanus gracilis in the eastern Central North Pacific, but they analyzed data sets that were collected from several different stations and exclusively consisted of late copepodid stages ( $\mathrm{C} 4$ to $\mathrm{C} 6$ ). In the present study, early stages ( $\mathrm{C} 1$ or $\mathrm{C} 2$ ) were always collected during the sampling period at St. B01, and no seasonal changes in copepodid compositions were observed. We likely underestimated the total abundances at St. B01, because adults, in particular, were distributed in deeper layers at stations where we did sample beyond $200 \mathrm{~m}$. However, our results at all stations showed that Stages C1 to C5 were mainly distributed between the surface and $200 \mathrm{~m}$ depth. Similarly, Stages C1 or C2 were always found in samples collected during each research cruise, although these were conducted in different seasons. These results indicate that $N$. gracilis is capable of yearround reproduction, as originally suggested by Mullin \& Evans (1976).

Seasonal and geographical differences in the vertical distribution of Neocalanus gracilis were not observed in the present study. Our results clearly indicated that C1 to C5 stages of N. gracilis were predominantly distributed in the surface layer, regardless of differences in the sampling season or location. However, among these stages, $\mathrm{C} 1$ occurred comparatively deeper than the other stages. Our results also indicated upward OVM between Stages C1 and C5. Similar results have previously been reported by Shmeleva \& Zaika (1973) and Mullin \& Evans (1976). In contrast to the early copepodid stages, the adults of $N$. gracilis were not only collected from the surface, but also from deeper horizons ( $>200 \mathrm{~m}$ ). Adult males (C6M), particularly, occurred mainly in the deeper layers. The deeper distribution of adult stages of $N$. gracilis has been reported by several authors (Chen 1986, Ambler \& Miller 1987, Gasser et al. 1998, Andersen et al. 2001). These results 


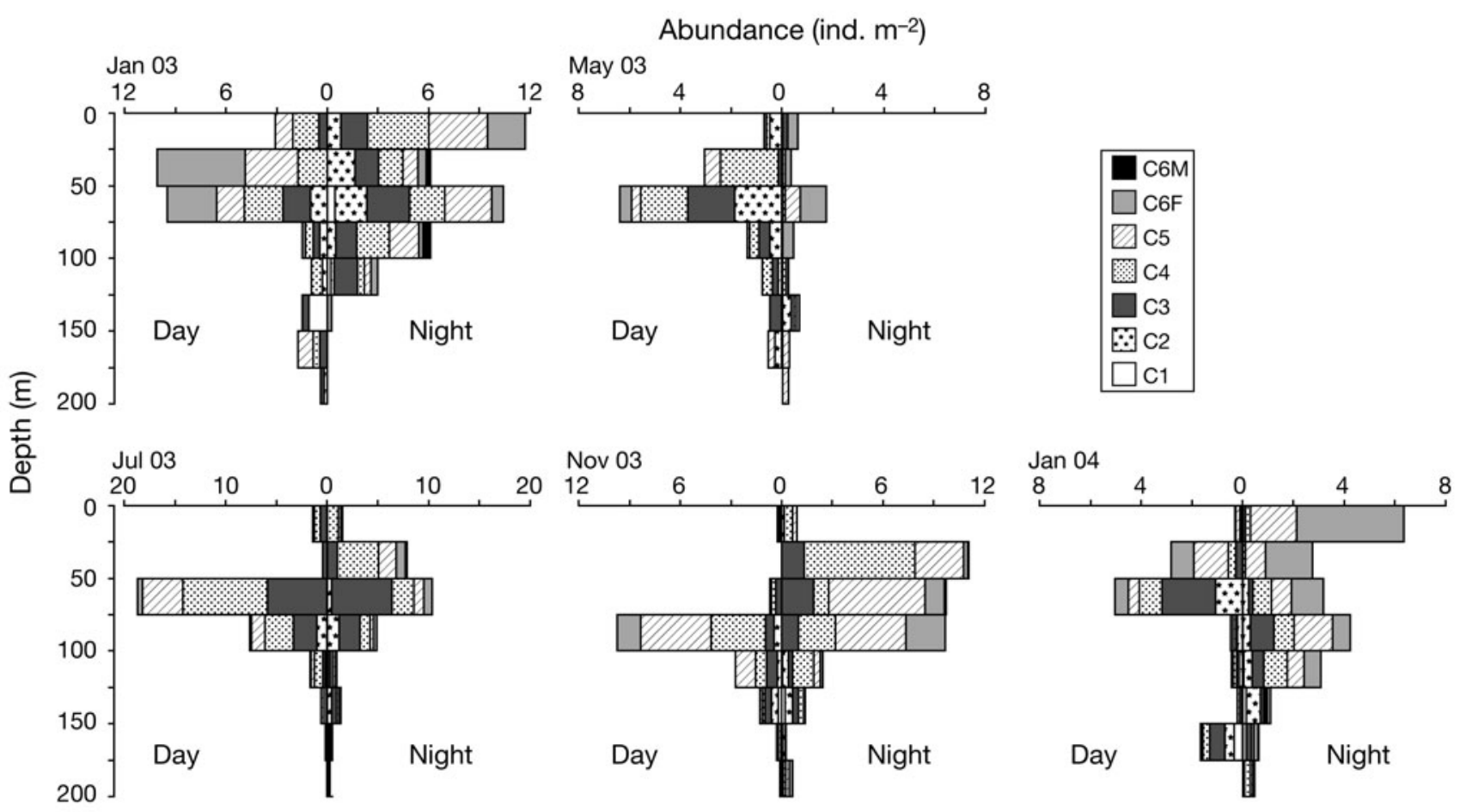

Fig. 6. Neocalanus gracilis. Day/night vertical distribution by developmental stage at St. B01

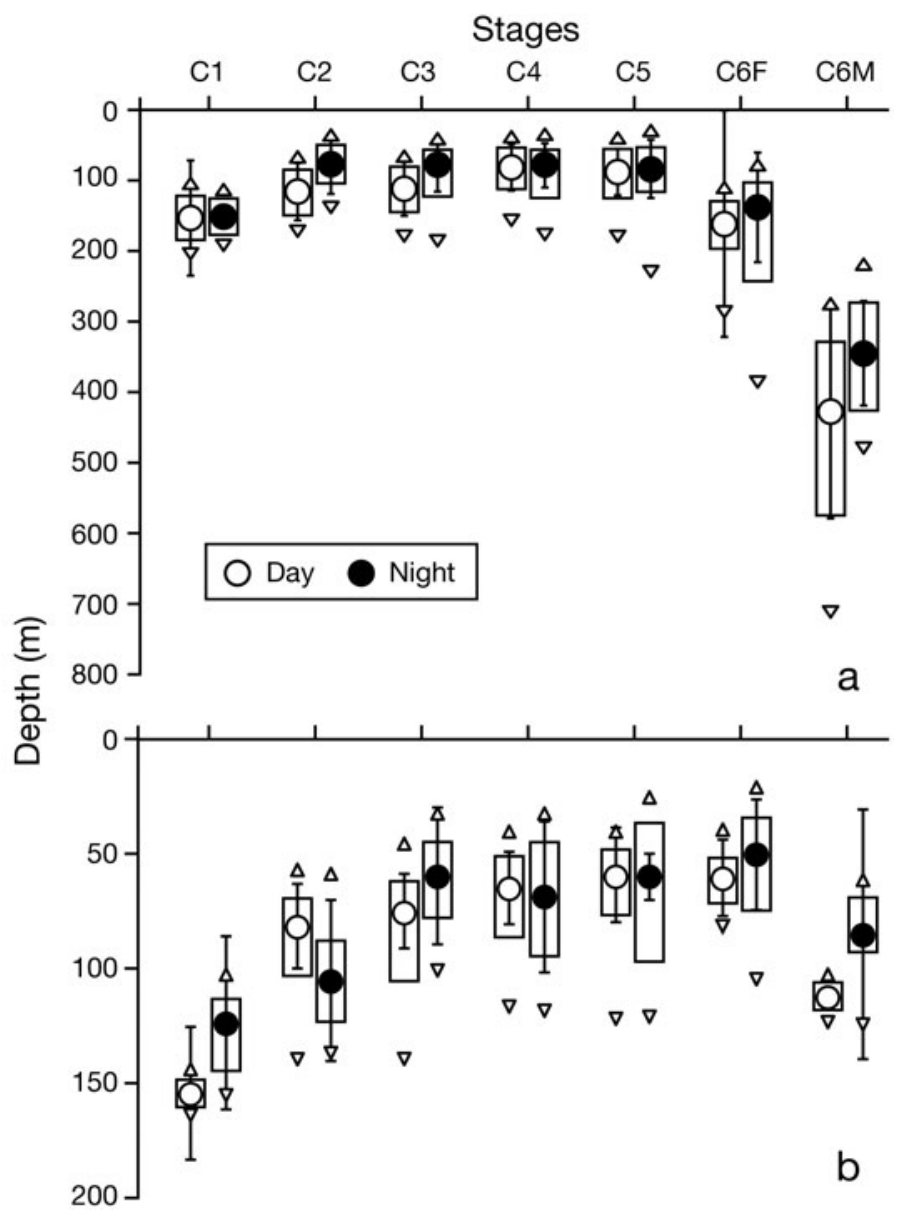

indicate that the OVM pattern of $N$. gracilis has 2 distinct traits, i.e. (1) the developmental ascent of early copepodid stages and (2) the developmental descent of adults. Developmental ascent behaviour has been observed in some meso- and bathypelagic copepods (e.g. Yamaguchi et al. 2004), whereas developmental descent is common among epipelagic species (e.g. Falkenhaug et al. 1997). According to Yamaguchi et al. (2004), these 2 different OVM strategies could be interpreted according to a 'predation pressure hypothesis', i.e. the strategies are determined by whether it is necessary for copepod species to reduce high predation pressure in the surface layers during early (deep-living species) or late (epipelagic species) copepodid stages. From this viewpoint, our results suggest that $N$. gracilis has mixed OVM strategies, reducing mortality due to predation during both the early and adult stages. Only the intermediate stages (C3 to C5), which we consider to have acquired a swimming

Fig. 7. Neocalanus gracilis. Diel and ontogenetic vertical migration by developmental stage at 14 stations (a) and St. B01 (b) in the western North Pacific. Circles indicate average depths of $\mathrm{D}_{50 \%}$; error bars $=\mathrm{SD}$. Open and closed symbols indicate day and night, respectively. Upper and lower triangles indicate depths of $\mathrm{D}_{10 \%}$ and $\mathrm{D}_{90 \%}$, respectively. Boxes show average depth ranges containing $50 \%$ of copepodid populations, i.e. upper and lower margins of the boxes indicate depths of $\mathrm{D}_{25} \%$ and $\mathrm{D}_{75} \%$, respectively (D: median depth, above and below [subscript, percent] which individuals were collected) 
ability sufficient to escape from predators, ascend to food-rich surface layers.

The deeper distributions of early copepodid stages imply subsurface egg production and/or egg hatching in deep layers. Mullin \& Evans (1976) suggested the possibility that eggs of Neocalanus gracilis might sink into deeper layers before hatching and that they may not be able to return to the surface during the nauplius stages. If this suggestion is correct, early developmental stages should adapt to survive in deeper, food-limited layers in a way similar to the non-feeding nauplius stages reported for the high-latitude congener N. cristatus (Saito \& Tsuda 2000). The oil droplet consistently observed in the prosome of Stage C1 supports this suggestion (Fig. 8). Considering that $N$. gracilis is one of the largest epipelagic copepods in subtropical and tropical waters, the ratio of predation risk/food gain of the species would increase synergistically in the surface layers. For this reason, the deeper distribution of the early copepodids of N. gracilis may decrease the mortality risk from visual predators and increase recruitment rate in subtropical and tropical oceans.

Reported DVM patterns of Neocalanus gracilis differ among earlier studies (e.g. Mullin \& Evans 1976, Andersen et al. 2001). Our results agreed with those of Andersen et al. (2001), indicating a weak or no DVM during Stages C1 to C5, whereas the adults displayed different DVM behaviours between sexes, which were clearly shown in the samples from $1000 \mathrm{~m}$ depth. Although day/night differences in $\mathrm{D}_{50 \%}$ did not markedly change in females, $\mathrm{D}_{90 \%}$ of females was lower further down the water column at night compared to during the day, which may imply reverse DVM (i.e. downward migration at night). On the other hand, the adult males were distributed below the surface layers, and their day/night difference in $\mathrm{D}_{50 \%}$ was the largest (ca. $82 \mathrm{~m}$ ) among all stages. In addition, the bulk distribution $\left(\mathrm{D}_{10 \%}\right.$ to $\left.\mathrm{D}_{90 \%}\right)$ of males at night tended to be narrower and shifted upwards, overlapping with the nighttime distribution of females. These vertical distribution and migration patterns suggest that the key factors controlling DVM behaviours were different between adult females and males. Females may need to stay and graze in the shallow, food-rich layers to fuel reproduction as well as to mate with males before starting egg production. In contrast, it would be reasonable for adult males to avoid the daytime surface layers, where predation pressure by visual predators is generally high, if they were in non-feeding stages, which is a common characteristic among Neocalanus species (Bradford 1988). Indeed, non-feeding types of male mouthparts were confirmed by our microscopic observations, i.e. undeveloped blades and lacking distal teeth in their mandibular gnathobases (Fig. 9). Thus, it seems that the purpose of nocturnal upward migration of adult males is to find and mate with females

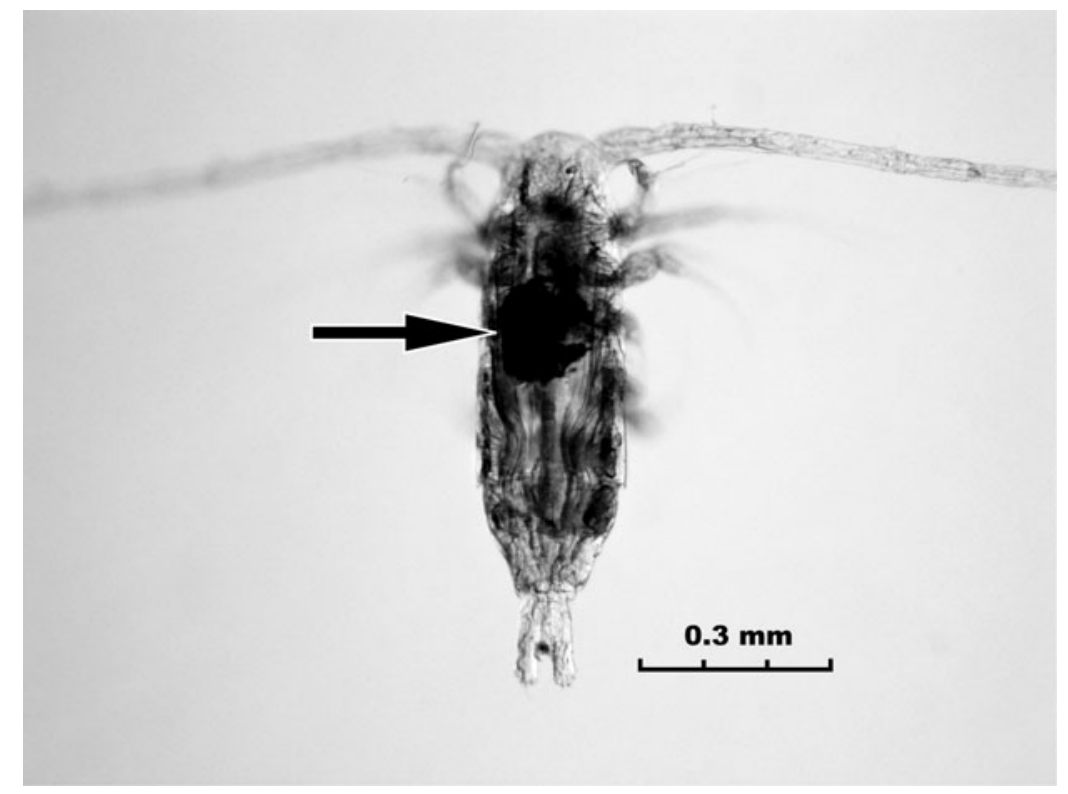

Fig. 8. Neocalanus gracilis Stage C1. Black arrow indicates an oil droplet in the prosome

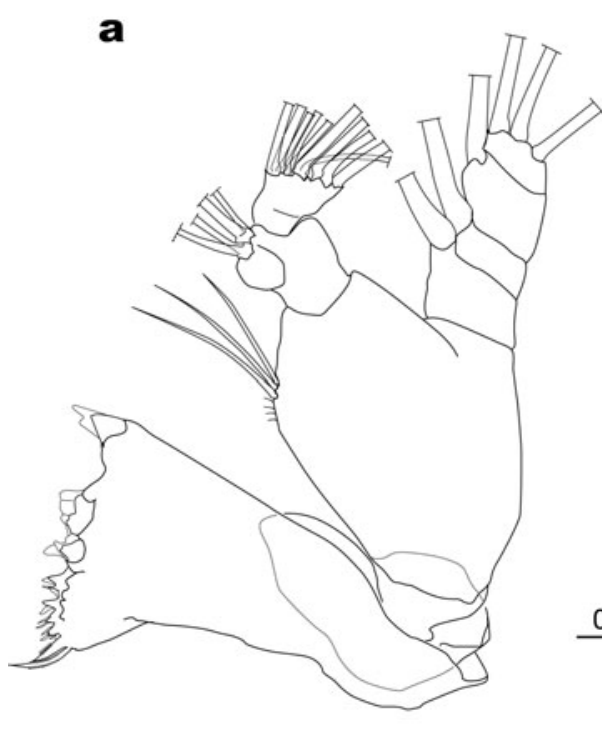

b

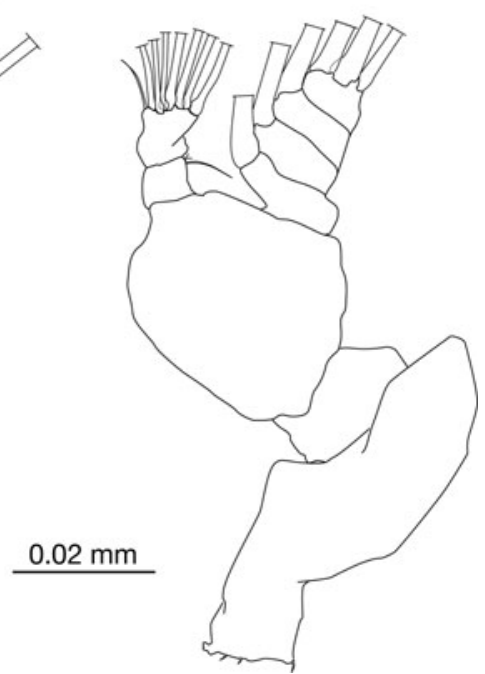

Fig. 9. Neocalanus gracilis. Mandibles of adult female (a) and male (b) 
in the upper layers. At the same time, some of the female population migrates downward from the surface at night, which may include unmated individuals. In summary, our results suggest that the vertical distribution of adult males is determined by a trade-off between mating with females and minimizing predation by visual predators in the surface layer.

Our results show that Neocalanus gracilis has the continuous breeding strategy typical of epipelagic copepods inhabiting subtropical and tropical oceans. On the other hand, without considering seasonality and deep dormant stages, the present study suggests some similarities in OVM strategies between N. gracilis and high-latitude Neocalanus species: (1) developmental ascent during early copepodid stages, (2) developmental descent in older stages and (3) nonfeeding males. The present results also imply that non-feeding nauplius stages are a common feature of $N$. gracilis and $N$. cristatus, as suggested by the lipid accumulations of Stage C1 copepodids. All highlatitude Neocalanus congeners perform seasonal OVMs between the surface and meso- or bathypelagic layers (e.g. Miller et al. 1984, Miller \& Clemons 1988) and exhibit lipid accumulation in their bodies for overwintering and reproduction (e.g. Ohman 1987, Conover 1988, Tsuda et al. 2001). It is generally thought that seasonal OVM is an adaptation to seasonal changes in primary production in the subarctic Pacific and subantarctic waters characterized by HNLC, where the phytoplankton standing stock is kept low by iron deficiency (Martin \& Fitzwater 1988, Boyd et al. 2000, Tsuda et al. 2003). In contrast, subtropical and tropical open oceans, except for upwelling regions, are known to be typical oligotrophic environments, where phytoplankton biomass is continuously low and its production is dominated by the small-size fraction of autotrophs (Li et al. 1983). Low-food conditions are considered to induce food competition among zooplankton species occupying a similar niche, as well as an increase in the mortality (predation) risk/energy (food) gain ratio (De Robertis 2002) in the surface layer. As for the larger body sizes of $N$. gracilis, the OVM strategy is considered to be beneficial for the successful recruitment in a manner that reduces mortality risk during the early and adult stages under oligotrophic conditions. These similar OVM traits among high- and low-latitude species might indicate phylogenetic commonalities in the life history of Neocalanus congeners. According to a study on the evolution of the genus Neocalanus based on molecular analysis (Machida et al. 2006), the first bifurcation within the genus occurs between the 'gracilis' group ( $N$. gracilis and $N$. robustior) and the 'tonsus' group (the other high-latitude Neocalanus species). Therefore, our finding implies that an ancestral Neocalanus species may potentially have had similar adaptive traits to oligotrophic environments. On an evolutionary time-scale, these adaptations to oligotrophic environments may be advantageous in allowing this genus to colonize subarctic and subantarctic HNLC regions, where phytoplankton assemblages are dominated by pico- and nanophytoplankton (Tsuda et al. 2003), as in tropical oceans. Moreover, the OVM pattern might have been modified to synchronize the life history to the local production patterns.

Acknowledgements. We sincerely thank the captains and crews of the RV 'Soyo-Maru' of the Fisheries Research Agency, Japan; the RV 'Hakuho-Maru' of the Ocean Research Institute, University of Tokyo, and the RV 'Hakurei-Maru No. 2' of Japan Oil, Gas and Metals National Corporation. We also sincerely thank Dr. T. Nonomura for lending sample collections and the technical staff of KANSO Co. Ltd. for assistance on board. Special thanks to the anonymous reviewers for helpful comments on our manuscript. This research was supported by the Grant-in-Aid for Scientific Research in Priority Areas 'Western Pacific Air-Sea Interaction Study (W-PASS)' under Grant No. 18067008 from the Ministry of Education, Culture, Sports, Science and Technology (MEXT), Japan and the project grant 'Evaluation, Adaptation and Mitigation of Global Warming in Agriculture, Forestry and Fisheries: Research and Development' from the Agriculture, Forestry and Fisheries Research Council, Japan. This research is a contribution to the Surface Ocean Lower Atmosphere Study (SOLAS) Core Project of the International GeosphereBiosphere Programme (IGBP).

\section{LITERATURE CITED}

Ambler JW, Miller CB (1987) Vertical habitat-partitioning by copepodites and adults of subtropical oceanic copepods. Mar Biol 94:561-577

Andersen V, Gubanova A, Nival P, Ruellet T (2001) Zooplankton community during the transition from spring bloom to oligotrophy in the open NW Mediterranean and effects of wind events. 2. Vertical distributions and migrations. J Plankton Res 23:243-261

Boyd PW, Watson AJ, Law CS, Abraham ER and others (2000) A mesoscale phytoplankton bloom in the polar Southern Ocean stimulated by iron fertilization. Nature 407: 695-702

Bradford JM (1988) Review of the taxonomy of the Calanidae (Copepoda) and the limits to the genus Calanus. Hydrobiologia 167/168:73-81

Bradford-Grieve JM, Nodder SD, Jillett JB, Currie K, Lassey KR (2001) Potential contribution that the copepod Neocalanus tonsus makes to downward carbon flux in the Southern Ocean. J Plankton Res 23:963-975

Chen YQ (1986) The vertical distribution of some pelagic copepods in the eastern tropical Pacific. CCOFI Rep 27: $205-227$

Conover RJ (1988) Comparative life histories in the genera Calanus and Neocalanus in high latitudes of the northern hemisphere. Hydrobiologia 167/168:127-142

De Robertis A (2002) Size-dependent visual predation risk and the timing of vertical migration: an optimization model. Limnol Oceanogr 47:925-933

Falkenhaug T, Tande KS, Semenova T (1997) Diel, seasonal 
and ontogenetic variations in the vertical distributions of four marine copepods. Mar Ecol Prog Ser 149:105-119

Gasser B, Payet G, Sardou J, Nival P (1998) Community structure of mesopelagic copepods $(>500 \mu \mathrm{m})$ in the Ligurian Sea (western Mediterranean). J Mar Syst 15:511-522

Hays GC, Warner AJ, Tranter P (1997) Why do the two most abundant copepods in the North Atlantic differ so markedly in their diel vertical migration behaviour? J Sea Res 38:85-92

Hopcroft RR, Roff JC (1998) Zooplankton growth rates: the influence of size in nauplii of tropical marine copepods. Mar Biol 132:87-96

Kobari T, Shinada A, Tsuda A (2003) Functional roles of interzonal migrating mesozooplankton in the western subarctic Pacific. Prog Oceanogr 57:279-298

Li WKW, Rao DVS, Harrison WG, Smith JC, Cullen JJ, Irwin B, Platt T (1983) Autotrophic picoplankton in the tropical ccean. Science 219:292-295

Machida RJ, Miya MU, Nishida M, Nishida S (2006) Molecular phylogeny and evolution of the pelagic copepod genus Neocalanus (Crustacea: Copepoda). Mar Biol 148: 1071-1079

Mackas DL, Tsuda A (1999) Mesozooplankton in the eastern and western subarctic Pacific: community structure, seasonal life histories, and interannual variability. Prog Oceanogr 43:335-363

Martin JH, Fitzwater SE (1988) Iron deficiency limits phytoplankton growth in the north-east Pacific subarctic. Nature 331:341-343

Miller CB, Clemons MJ (1988) Revised life history analysis for large grazing copepods in the subarctic Pacific Ocean. Prog Oceanogr 20:293-313

Miller CB, Frost BW, Batchelder HP, Clemons MJ, Conway RE (1984) Life histories of large, grazing copepods in a subarctic ocean gyre: Neocalanus plumchrus, Neocalanus cristatus, and Eucalanus bungii in the Northeast Pacific. Prog Oceanogr 13:201-243

Editorial responsibility: Angus Atkinson, Cambridge, UK
Mullin MM, Evans PM (1976) Distribution, morphometry, and seasonal biology of planktonic copepods Neocalanus robustior and Neocalanus gracilis in the Pacific Ocean. Pac Sci 30:119-130

Ohman MD (1987) Energy sources for recruitment of the subantarctic copepod Neocalanus tonsus. Limnol Oceanogr 32:1317-1330

Pennak RW (1943) An effective method of diagramming diurnal movements of zooplankton organisms. Ecology 24: 405-407

Roe HSJ (1972) The vertical distributions and diurnal migrations of calanoid copepods collected on the SOND cruise, 1965. II. Systematic account: families Calanidae up to and including the Aetideidae. J Mar Biol Assoc UK 52:315-343

Saito H, Tsuda A (2000) Egg production and early development of the subarctic copepods Neocalanus cristatus, N. plumchrus and N. flemingeri. Deep Sea Res I 47:2141-2158

Shmeleva AA, Zaika VE (1973) Vertical distribution of copepodite stages of copepods in the Adriatic Sea. Okeanologiya 13:872-876

Terazaki M, Tomatsu C (1997) A vertical multiple opening and closing plankton sampler. J Adv Mar Sci Tech Soc 3: $127-132$

Tsuda A, Saito H, Kasai H (2001) Life history strategies of subarctic copepods Neocalanus flemingeri and N. plumchrus, especially concerning lipid accumulation patterns. Plankton Biol Ecol 48:52-58

Tsuda A, Takeda S, Saito H, Nishioka J and others (2003) A mesoscale iron enrichment in the western subarctic Pacific induces a large centric diatom bloom. Science 300:958-961

Webber MK, Roff JC (1995) Annual biomass and production of the oceanic copepod community off Discovery Bay, Jamaica. Mar Biol 123:481-495

Yamaguchi A, Ikeda T, Watanabe Y, Ishizaka J (2004) Vertical distribution patterns of pelagic copepods as viewed from the predation pressure hypothesis. Zool Stud 43: 475-485

Submitted: June 5, 2009; Accepted: October 13, 2009

Proofs received from author(s): November 25, 2009 